\title{
Development of the recipe and technology of dessert butter with black currant
}

\author{
Inessa Zachesova*, Maria Gorbacheva, Anna Merkylova, and Natalia Shagaeva
}

Moscow State Academy of Veterinary Medicine and Biotechnology - MVA named after K.I.

Skryabin, 109472, Moscow, str. Akademika Skryabina, 23, Russia

\begin{abstract}
Butter is in constant demand among consumers, as it has a high nutritional and energy value. However, the range of butter sold in the retail chain is represented by such names as Traditional, Amateur, Peasant, Chocolate. In this connection, there is a need to create new types of butter with high consumer properties. The technology and recipes of dessert butter with black currant have been developed. The analysis of organoleptic and physico-chemical indicators of the quality of the developed butter with black currant is carried out. The optimal amount of black currant is determined when creating dessert butter.
\end{abstract}

Butter has a high nutritional and energy value. Butter can contain up to $85 \%$ of milk fat, which causes its high energy value-about $790 \mathrm{kcal} / 100 \mathrm{~g}$. In its composition, butter contains fat-soluble vitamins $\mathrm{A}, \mathrm{E}$, as well as water-soluble vitamins $-\mathrm{B}_{1}, \mathrm{~B}_{2}, \mathrm{C}$. In addition to glycerides of various fatty acids, the oil contains more than 50 different chemical components. Excellent taste, aroma, balanced amount of volatile fatty acids, high content of fat-soluble vitamins, high digestibility of nutrients makes the oil an indispensable product $[1,2,3]$.

In the laboratory, samples of butter were made with the addition of black currant jam, which was added to the oil in the following amounts: sample № $1-10 \%$, sample № $2-15$ $\%$, sample № $3-20 \%$ and sample № $4-25 \%$ by weight of the raw material.

The recipe for butter with the addition of black currant is presented in Table 1.

Table 1. The recipe of butter with a taste component of black currant.

\begin{tabular}{|l|c|c|c|c|}
\hline \multirow{2}{*}{ Components } & \multicolumn{4}{c|}{ Sample } \\
\cline { 2 - 5 } & № 1 & № 2 & № 3 & № 4 \\
\hline Sweet butter "Traditional" not salty & 90 & 85 & 80 & 75 \\
\hline Blackcurrant jam & 10 & 15 & 20 & 25 \\
\hline Total & 100 & 100 & 100 & 100 \\
\hline
\end{tabular}

The recipe for black currant jam is given in Table 2 .

\footnotetext{
*Corresponding author: inessa_zachesova@mail.ru
} 
Table 2. Recipe for blackcurrant jam.

\begin{tabular}{|l|c|}
\hline \multicolumn{1}{|c|}{ Components } & Raw materials, kg per $100 \mathrm{~kg}$ \\
\hline Frozen blackcurrant & 50 \\
\hline White sugar & 50 \\
\hline Total & 100 \\
\hline
\end{tabular}

The production of butter with black currant consists of the steps shown in Figure 1. Butter "Traditional" sweet and creamy unsalted on the table (7) is melted, heated to a temperature in the thickness of the monolith $18-20^{\circ} \mathrm{C}$, cut into pieces weighing from 1 to 5 $\mathrm{kg}$. Next, the oil enters the agitator (5). Jam is made from frozen blackcurrant berries, which are sent to the table (1) for sorting, then the currants are sent to the wiping machine (2), in which the berries are crushed. Next, the crushed berries are fed to a vacuum evaporation unit (3), where they are mixed with sugar and cooked for 20-25 minutes at a temperature of $80 \pm 2{ }^{\circ} \mathrm{C}$. The finished jam enters the storage tank (4), where it is cooled to a temperature of $60^{\circ} \mathrm{C}$, then enters the agitator (5). In the agitator (5), the black currant jam is thoroughly mixed with the softened butter until a homogeneous consistency is achieved. The finished butter is fed into the hopper of the body of the oil-forming machine (6), from where it is pressed through the nozzle with the help of two screws and then fed to the consumer packaging in the form of briquettes weighing $180 \mathrm{~g}$ of cased foil $[4,5,6,7]$.

The finished product is stored in refrigeration units at a storage temperature $(3 \pm 2)^{\circ} \mathrm{C}-10$ days, or at a storage temperature of minus $(6 \pm 3)^{\circ} \mathrm{C}-90$ days, or at a storage temperature of minus $(16 \pm 2)^{\circ} \mathrm{C}-120$ days.

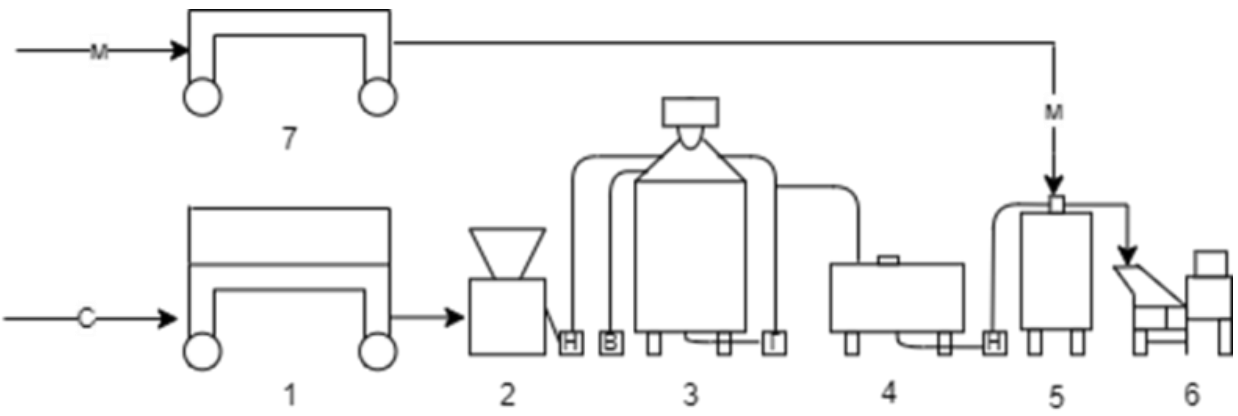

Fig. 1. Hardware and technological scheme of production of butter with black currant.

After producing samples of dessert butter with black currant, organoleptic studies were conducted (Table 3).

From the data in Table 3, it can be seen that the samples of butter with black currant had different organoleptic quality indicators. Samples № 1 and № 2 had a pronounced creamy taste, but the taste of currant was not bright enough. Sample № 3 had a sweet, creamy taste with a pronounced taste and smell of black currant. Sample № 4 had a pronounced taste and smell of black currant, but had an excessively sour taste.

The organoleptic assessment of the quality of butter on a 20-point scale is shown in Table 4. 
Table 3. Organoleptic indicators of the quality of butter with black currant.

\begin{tabular}{|c|c|c|c|c|}
\hline \multirow{2}{*}{ Indicator name } & \multicolumn{4}{|c|}{ Sample } \\
\hline & № 1 & № 2 & № 3 & № 4 \\
\hline $\begin{array}{l}\text { Taste and } \\
\text { smell }\end{array}$ & $\begin{array}{l}\text { Pronounced } \\
\text { creamy taste, } \\
\text { almost } \\
\text { imperceptible } \\
\text { taste of black } \\
\text { currant }\end{array}$ & $\begin{array}{l}\text { Pronounced } \\
\text { creamy, but not } \\
\text { sufficiently } \\
\text { pronounced } \\
\text { sweet taste and } \\
\text { taste of black } \\
\text { currant } \\
\end{array}$ & $\begin{array}{c}\text { Creamy, with } \\
\text { a pronounced } \\
\text { taste and smell } \\
\text { of black } \\
\text { currant; } \\
\text { moderately } \\
\text { sweet } \\
\end{array}$ & $\begin{array}{c}\text { Imperceptible } \\
\text { creamy taste, with a } \\
\text { pronounced taste and } \\
\text { smell of black } \\
\text { currant; sweet and } \\
\text { sour }\end{array}$ \\
\hline $\begin{array}{c}\text { Consistency } \\
\text { and appearance }\end{array}$ & $\begin{array}{c}\text { The } \\
\text { consistency is } \\
\text { plastic, } \\
\text { homogeneous. } \\
\text { The surface on } \\
\text { the cut is dry; } \\
\text { with a small } \\
\text { amount of } \\
\text { black currant } \\
\text { particles }\end{array}$ & $\begin{array}{l}\text { The consistency } \\
\text { is plastic, } \\
\text { homogeneous. } \\
\text { The surface is } \\
\text { slightly flat, with } \\
\text { a small amount } \\
\text { of black currant } \\
\text { particles }\end{array}$ & $\begin{array}{c}\text { The } \\
\text { consistency is } \\
\text { plastic, } \\
\text { homogeneous. } \\
\text { The surface is } \\
\text { shiny, with } \\
\text { moderate } \\
\text { inclusions of } \\
\text { blackcurrant } \\
\text { particles }\end{array}$ & $\begin{array}{l}\text { The consistency is } \\
\text { plastic, } \\
\text { homogeneous. The } \\
\text { surface is shiny, with } \\
\text { a lot of black currant } \\
\text { particles }\end{array}$ \\
\hline Colour & $\begin{array}{l}\text { Light pink } \\
\text { color, uniform } \\
\text { throughout the } \\
\text { mass }\end{array}$ & $\begin{array}{l}\text { Light pink color, } \\
\text { uniform } \\
\text { throughout the } \\
\text { mass }\end{array}$ & $\begin{array}{c}\text { Pink color, } \\
\text { uniform } \\
\text { throughout the } \\
\text { mass }\end{array}$ & $\begin{array}{l}\text { Dark pink color, } \\
\text { uniform throughout } \\
\text { the }\end{array}$ \\
\hline
\end{tabular}

Table 4. Organoleptic assessment of the quality of butter with black currant on a 20-point scale.

\begin{tabular}{|l|c|c|c|c|c|}
\hline \multirow{2}{*}{ Indicator name } & \multicolumn{5}{|c|}{ Rating, point } \\
\cline { 2 - 6 } & \multirow{2}{*}{$\begin{array}{c}\text { Maximum number } \\
\text { of points }\end{array}$} & \multicolumn{5}{c|}{ Sample } \\
\cline { 3 - 6 } & 11 & 9 & 10 & 11 & 8 \\
\hline Taste and smell № 1 & № 2 & № 3 & № 4 \\
\hline $\begin{array}{l}\text { Consistency } \\
\text { appearance }\end{array}$ & 6 & 5 & 5 & 6 & 5 \\
\hline Colour & 3 & 2 & 2 & 3 & 3 \\
\hline Total & 20 & 16 & 17 & 20 & 16 \\
\hline
\end{tabular}

From the data in Table 4, it can be seen that sample No. 3 received a maximum score of 20 points for organoleptic quality indicators, in contrast to samples of butter № 1, № 2 and № 4, which received scores of 16,17 and 16 points, respectively.

Chemical studies of butter were carried out on such indicators as the mass fraction of moisture, fat, and dry matter (Table 5).

Table 5. Chemical indicators of the quality of butter with black currant.

\begin{tabular}{|l|c|c|c|c|}
\hline \multirow{2}{*}{\multicolumn{1}{|c|}{ Indicator name }} & \multicolumn{4}{c|}{ Sample } \\
\cline { 2 - 5 } & № 1 & № 2 & № 3 & № 4 \\
\hline Mass fraction of fat, \% & 62,8 & 59,8 & 57,2 & 54,2 \\
\hline Mass fraction of moisture, \% & 23,4 & 26,2 & 28,4 & 31,3 \\
\hline Mass fraction of dry substances, \% & 13,6 & 13,8 & 14,2 & 14,5 \\
\hline
\end{tabular}


From the data in Table 5, it can be seen that the chemical parameters of butter samples № 1, 2 and 4 did not meet the requirements of the regulatory documentation.

Samples № 1 and № 2 did not meet the requirements of the regulatory documentation, since the value of the indicator mass fraction of dry substances is less than the established standards. Sample № 4 did not meet the requirements of the regulatory documentation, since the value of the mass fraction of fat indicator was less than the established norms, the value of the mass fraction of moisture indicator was higher than the established norms. Sample № 3 met the requirements of the regulatory documentation in terms of chemical quality indicators [8].

As a result of organoleptic and chemical studies, it was found that the optimal amount of black currant application in the recipe of dessert butter is $20 \%$ by weight of the raw material.

The developed recipe and technology of dessert butter with black currant allows you to intensify the production process of the product, improve consumer properties, as the taste component gives the finished product original organoleptic properties: the taste, aroma, color, and also reduces the caloric content of the finished product.

\section{References}

1. K.A. Romashkina, I.A. Zachesova, Tserevitinovsky readings-2017, Comparative characteristics of butter from various manufacturers.165-166.(2017)

2. G.V. Chebakova, M.V. Gorbacheva, K.V. Esepenok, Fundamentals of processing technology and commodity science of food products from raw materials of animal origin (2021)

3. N.A. Adamov, M.V. Gorbacheva, Commodity expert of food products, Oil and fat industry: current state and prospects of development, 12, 32-35 (2018)

4. T.P. Arsenyeva, Butter technology, 177 - 186 (2013)

5. G.V. Kozhukhova, A method for producing butter (variants) (2009)

6. Yu. A. Shchepochkina, A method for preparing butter with honey bee (2011)

7. E.P. Kornena, T.B. Brikota, S.A. Kalmanovich, N.A. Monakhova, V.V. Petrova, O.P. Petrik, I.G. Mkhitaryants, Method of cooking butter (2008)

8. GOST 32899-2014. Butter with flavoring components. Technical specifications, 20 (2015) 